\title{
North Atlantic right whale habitat in the lower Bay of Fundy and on the SW Scotian Shelf during 1999-2001
}

\author{
Mark F. Baumgartner ${ }^{1,4, *}$, Tim V. N. Cole ${ }^{2}$, Phillip J. Clapham ${ }^{2}$, Bruce R. Mate ${ }^{3}$ \\ ${ }^{1}$ College of Oceanic and Atmospheric Sciences, Oregon State University, 104 Ocean Administration Building, Corvallis, \\ Oregon 97331, USA \\ ${ }^{2}$ National Marine Fisheries Service, Northeast Fisheries Science Center, 166 Water Street, Woods Hole, Massachusetts 02543, USA \\ ${ }^{3}$ Coastal Oregon Marine Experiment Station, Hatfield Marine Science Center, Oregon State University, Newport, Oregon \\ 97365, USA
}

${ }^{4}$ Present address: Biology Department, MS \#33, Woods Hole Oceanographic Institution, Woods Hole, Massachusetts 02543, USA

\begin{abstract}
Simultaneous visual and oceanographic surveys were conducted in the lower Bay of Fundy and in Roseway Basin of the SW Scotian Shelf during the summers of 1999 to 2001 to investigate the physical and biological oceanographic factors associated with North Atlantic right whale occurrence. Sightings of right whales were recorded along predetermined transects through each region, while both in situ and remotely sensed oceanographic measurements were collected. Sampling with plankton nets and an optical plankton counter confirmed that right whales in these regions feed on Calanus finmarchicus copepodite stage 5 (C5). Spatial variability in right whale occurrence was associated with water depth and the depth of the bottom mixed layer. C. finmarchicus C5 aggregated over the deepest water depths in both regions, and within these areas, right whales occurred where the bottom mixed layer forced discrete layers of $C$. finmarchicus $\mathrm{C} 5$ to occur shallower in the water column (allowing more efficient foraging). Annual increases in right whale occurrence appeared to be associated with decreases in sea surface temperature (SST) in both regions; however, this observation merits caution in light of the short duration of the study ( $3 \mathrm{yr}$ ). There was also evidence to suggest that both spatial and interannual variability in right whale occurrence in Roseway Basin may be associated with SST gradient, a proxy for ocean fronts.
\end{abstract}

KEY WORDS: Eubalaena glacialis · Distribution · Habitat · Calanus finmarchicus $\cdot$ Fronts $\cdot$ Gulf of Maine $\cdot$ Roseway Basin $\cdot$ AVHRR $\cdot$ SeaWiFS $\cdot$ Optical plankton counter

\section{INTRODUCTION}

Despite protection from hunting since the mid 1930s, the North Atlantic right whale Eubalaena glacialis remains one of the most endangered species of large whales (Clapham et al. 1999). Mortality from fishing gear entanglement and collisions with ships is of great concern (Kraus 1990, Kenney \& Kraus 1993, Knowlton \& Kraus 2001) and conservation efforts may be improved with the protection of right whale habitat. However, our understanding of what constitutes right whale habitat is quite poor. Many studies have indicated that the presence of large aggregations of the right whale's primary prey, older stages of the calanoid copepod Calanus finmarchicus, is probably the single most important component of right whale habitat (Watkins \& Schevill 1976, Wishner et al. 1988, 1995, Murison \& Gaskin 1989, Mayo \& Marx 1990, Beardsley et al. 1996, Woodley \& Gaskin 1996, Kenney 2001). However, the physical and biological oceanographic features or conditions that promote high abundance and discrete aggregation of this prey over time and space 
are not well understood, nor are the means by which right whales locate and exploit these food resources.

North Atlantic right whales occur in Cape Cod and Massachusetts Bays in the late winter and early spring, where they primarily feed on Calanus finmarchicus, but have also been observed feeding on Pseudocalanus spp., Centropages spp., barnacle larvae and euphausiids (Watkins \& Schevill 1976, Mayo \& Marx 1990). By mid-spring, right whales are typically found in the Great South Channel (Kenney et al. 1995). Here again, they primarily feed on older copepodite stages of C. finmarchicus (Wishner et al. 1988, 1995). In the later summer, right whales occupy the lower Bay of Fundy (Kraus et al. 1982) or the southwestern Scotian Shelf (Mitchell et al. 1986). Murison \& Gaskin (1989) and Woodley \& Gaskin (1996) concluded that the primary prey of right whales in the lower Bay of Fundy was C. finmarchicus, and Stone et al. (1988) observed C. finmarchicus mandibles in right whale feces collected in Roseway Basin on the southwestern Scotian Shelf. By late fall, right whales abandon the lower Bay of Fundy and, while some animals migrate southward to the only known calving grounds on the coast of the southeastern United States, the whereabouts of the rest of the population in late fall and early winter are currently unknown. Although these seasonal movements between high-use areas have been well documented for some time (CETAP 1982, Winn et al. 1986), recent data acquired from whales outfitted with satellite-monitored radio tags suggest that interregional movements on much shorter time scales are quite common (Mate et al. 1997). Alterations in the seasonal distribution of right whales have also been observed in some years (Payne et al. 1990, Kenney 2001), and there is evidence of other potential high-use areas (Weinrich et al. 2000).

Our study focused on the ecological relationship between right whale occurrence and several biological and physical oceanographic factors in the lower Bay of Fundy and in Roseway Basin on the southwestern Scotian Shelf during the summers of 1999 to 2001. We collected and examined data from visual surveys and from both in situ and satellite-borne oceanographic instrumentation to characterize right whale habitat features. We paid particular attention to the occurrence of right whales and the abundance and distribution of the most lipid-rich stage of their prey, Calanus finmarchicus copepodite stage 5 (C5), to identify relationships linking the physical environment, C. finmarchicus and right whales. These relationships were examined separately over space and time to determine the factors that influence right whale occurrence. Based on these findings, we hope to provide a scientific foundation upon which right whale distribution can be predictively modeled for conservation purposes.

\section{MATERIALS AND METHODS}

Data collection and processing. Simultaneous visual and oceanographic surveys were conducted in the lower Bay of Fundy and Roseway Basin during the summers of 1999, 2000 and 2001. North-south (Bay of Fundy) and east-west (Roseway Basin) transects were visually surveyed through a grid of oceanographic stations (Fig. 1). A single survey unit consisted of a $9.3 \mathrm{~km}$ (5 nautical miles [n miles]) transect section centered on an oceanographic station. The survey unit length was selected as the approximate scale of horizontal variability in hydrographic properties observed on the Scotian Shelf by Herman et al. (1991). The width of the survey unit was estimated from the maximum distance perpendicular to the trackline at which a right whale was detected during the surveys. This distance was approximately $4.6 \mathrm{~km}$ (2.5 n miles), so a single survey unit was defined as a $9.3 \times 9.3 \mathrm{~km}(5 \times 5 \mathrm{n}$ miles $)$ area centered on an oceanographic station. Surveys were conducted during cruises designed to accommodate several research objectives, so not all survey units were sampled each year. After 1999 in the lower Bay of Fundy, the present study competed with research objectives that required fair weather conditions and calm seas, so surveys were typically conducted in slightly higher sea states (Beaufort scale 2-5). Each region (lower Bay of Fundy and Roseway Basin) was sampled once per summer except in 2000 when the lower Bay of Fundy was sampled twice (Fig. 2).

Visual surveys were conducted from the flying bridge of NOAA Ship 'Delaware II'. Two observers used mounted, $25 \times 150$, 'big eye' binoculars to scan from roughly -90 to $+90^{\circ}$ relative to the bow while a third observer scanned with hand-held binoculars or with the naked eye. Sightings of marine mammals were recorded by this third observer using a handheld data-entry system. The date, time, species, number of individuals and the distance and relative bearing to the animal or animals were logged for each encounter. The location of each sighting was later computed along a rhumb line using the observer's bearing and distance estimates and the ship's simultaneous GPS and gyro compass measurement. Sighting conditions, including sea state, glare magnitude and direction, visibility and swell height, were also recorded during the surveys, using either paper forms or the hand-held data-entry system. Visual effort was conducted only while steaming along a transect and not while on station. Ship speed during surveys was nominally $18.5 \mathrm{~km} \mathrm{~h}^{-1}$ (10 knots).

An instrument package, consisting of a Seabird model SBE19 conductivity-temperature-depth instrument (CTD) and a Focal Technologies model OPC-1T optical plankton counter (OPC), was deployed in a 


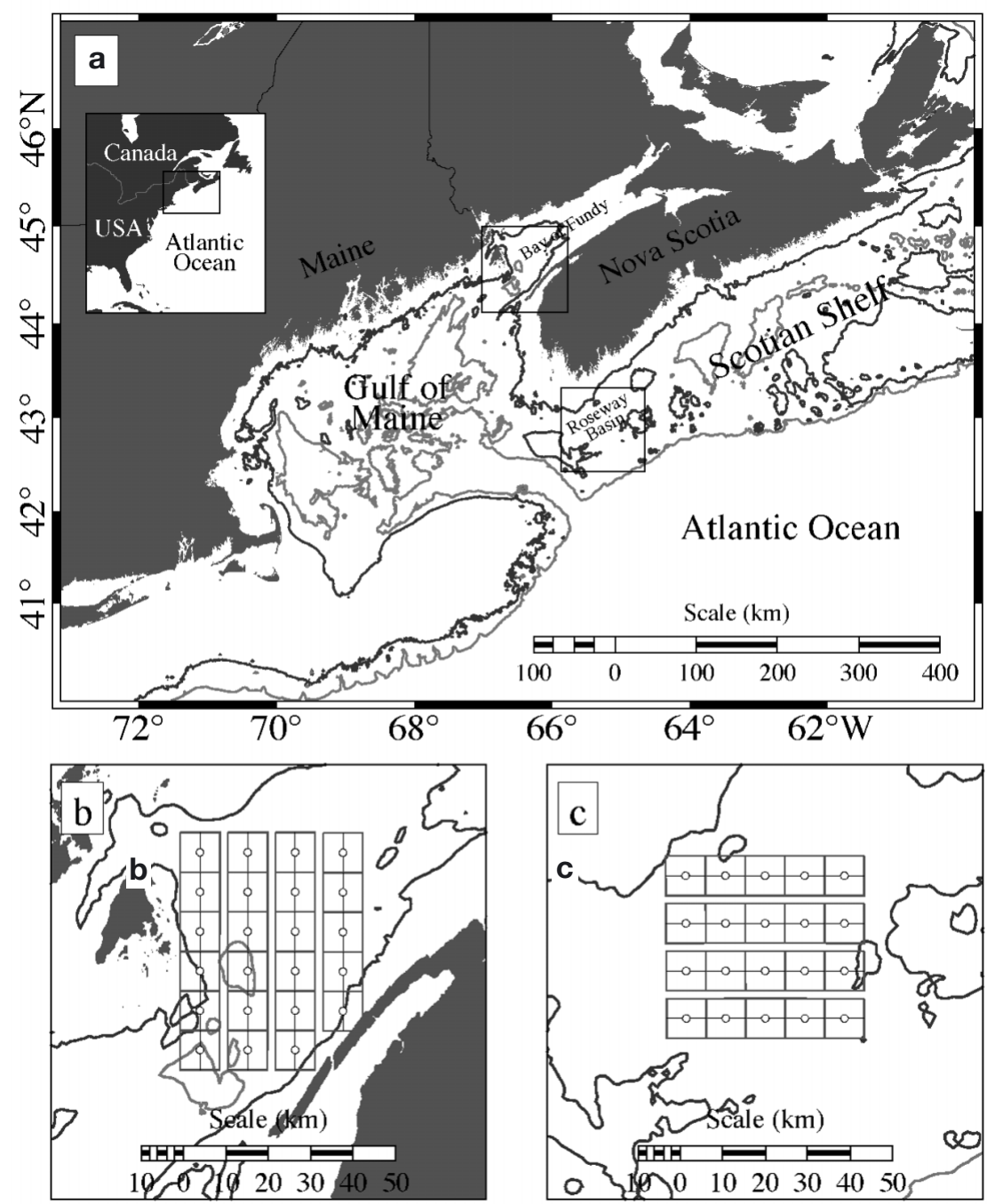

Fig. 1. (a) Location of study areas in the lower Bay of Fundy and Roseway Basin. Survey transects (black lines), oceanographic stations (o) and survey units (gray boxes) in (b) the lower Bay of Fundy and (c) Roseway Basin. 91 m (50 fathom) and $200 \mathrm{~m}$ isobaths are shown vertical cast at each station. The CTD provided vertical profiles of temperature and salinity while the OPC (Herman $1988,1992)$ recorded the vertical distribution of particles between 0.25 and $20 \mathrm{~mm}$ in size. The vertical distribution of Calanus finmarchicus C5 was estimated from the OPC data in $4 \mathrm{~m}$ depth strata using the calibration equation developed by Baumgartner (2003) from comparisons between collocated OPC casts and net samples collected during these same cruises.

Concurrent, high resolution, remotely sensed data were also collected from an advanced, very high resolution radiometer (AVHRR) and the sea-viewing, wide field-of-view sensor (SeaWiFS) and processed into sea surface temperature (SST) and surface chlorophyll, respectively. The AVHRR data were processed and archived at the University of Rhode Island (Cornillon et al. 1987) while the SeaWiFS data were processed using the SeaDAS software package (version 4.0). Synoptic images from both sensors were transformed to an equidistant, cylindrical projection (i.e. linear latitude/longitude) at a nominal resolution of $1.1 \times 1.1 \mathrm{~km}$ and manually co-registered with a digital coastline. Horizontal gradients of both sea surface temperature and surface chlorophyll were computed using a $3 \times 3$ pixel Sobel gradient operator (Russ 1995). A single, cloud-free, remotely-sensed image within $\pm 3 \mathrm{~d}$ of a survey day was selected and the corresponding SST or surface chlorophyll as well as its respec-

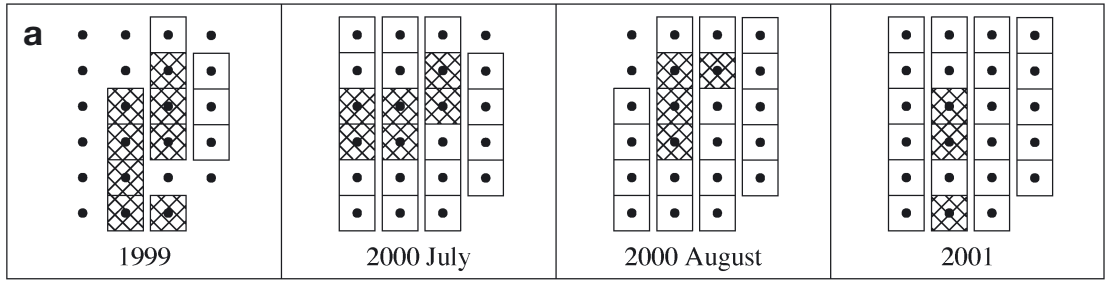

Fig. 2. Eubalaena glacialis. Visual survey results for (a) the lower Bay of Fundy and (b) Roseway Basin. Station plan $(\bullet)$ and completed survey units (boxes) are indicated. Survey units with 1 or more right whales sighted are cross-hatched. Dates of surveys are provided in Table 2

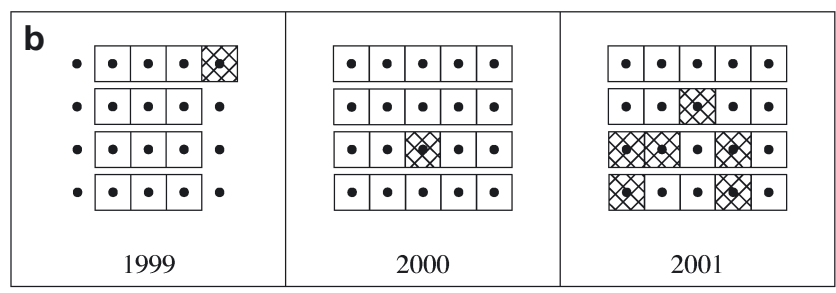


tive horizontal gradient magnitude were averaged over each $9.3 \times 9.3 \mathrm{~km}$ unit surveyed on that day. The median time between midday on a survey day and the corresponding satellite overpass was 0.95 and $1.2 \mathrm{~d}$ for AVHRR and SeaWiFS images, respectively. Although higher frequency variability in SST and surface chlorophyll is expected within the $\pm 3 \mathrm{~d}$ temporal window (e.g. diurnal warming, tidal excursion of fronts), spatial and interannual variability in these properties at the scales examined here should be much larger in magnitude. Therefore, the $\pm 3 \mathrm{~d}$ temporal window is considered appropriate.

Zooplankton samples were obtained periodically in the lower Bay of Fundy and Roseway Basin both in the presence (within a few hundred meters) and absence of right whales. Depth integrated samples were collected with a $61 \mathrm{~cm}$ diameter bongo frame equipped with $333 \mu \mathrm{m}$ mesh nets and 2 General Oceanics digital flowmeters. In the lower Bay of Fundy during 2001, depth-stratified samples were also obtained using a multiple opening-closing net and environmental sensing system (MOCNESS; Wiebe et al. 1976, 1985) equipped with $150 \mu \mathrm{m}$ mesh nets. Zooplankton sampling was conducted in all years from NOAA Ship 'Delaware II' and additional sampling was conducted from NOAA Ship 'Albatross IV' in 2001. Samples were preserved immediately after collection in a boratebuffered, $5 \%$ formalin-seawater solution. Subsamples containing approximately 100 or more of the most abundant species were drawn with a Hensen-stemple pipette and all organisms in each subsample were identified and enumerated to the lowest taxon possible. Abundance estimates of Calanus finmarchicus C5 from the nets were compared to OPC-derived abundances observed in survey units with and without right whales, as well as to OPC-derived abundances observed near right whales $(<300 \mathrm{~m}$ away) tagged with time-depth recorders (data from Baumgartner \& Mate 2003 this issue).

Environmental variables. Right whale occurrence was investigated with respect to 16 environmental variables (Table 1). Water depth was measured at each oceanographic station with a Simrad model EK500 scientific echosounder. A $1.1 \times 1.1 \mathrm{~km}$ resolution digital bathymetric dataset was compiled from a variety of sounding and gridded bathymetric sources (e.g. National Ocean Service soundings, $2 \times 2$ min topographic data [Smith \& Sandwell 1997], ETOPO5 gridded bathymetry [NGDC 1988]) and depth gradient magnitude was computed from this dataset using the same $3 \times 3$ pixel Sobel gradient operator used for the AVHRR and SeaWiFS data. Both depth and depth gradient are important habitat descriptors for a variety of cetacean species (Hui 1979, 1985, CETAP 1982, Selzer \& Payne 1988, Baumgartner 1997, Baumgartner et al. 2001).

Murison \& Gaskin (1989) and Woodley \& Gaskin (1996) suggested that right whales in the lower Bay of Fundy occupy waters with high surface stratification. Accordingly, changes in both density and temperature over the upper $50 \mathrm{~m}$ of the water column were extracted from the CTD data and analyzed. Baumgartner \& Mate (2003) reported that right whales equipped with archival tags foraged just above the bottom mixed layer (BML) in the lower Bay of Fundy and Roseway Basin. Therefore, BML properties were derived from the CTD data and included in the analysis. BML depth was defined as the deepest depth at

Table 1. Environmental variables used in the habitat analyses. BML: bottom mixed layer; SST: sea surface temperature; CTD: conductivity-temperature-depth instrument; OPC: optical plankton counter; AVHRR: advanced, very high resolution radiometer; SeaWiFS: sea-viewing, wide field-of-view sensor

\begin{tabular}{|c|c|c|}
\hline Variable & Source & Units \\
\hline Depth & Ship echosounder & $\mathrm{m}$ \\
\hline Depth gradient & Digital bathymetry & $\mathrm{m} \mathrm{km}^{-1}$ \\
\hline Surface stratification (density) & $\mathrm{CTD}^{1}$ & $\mathrm{~kg} \mathrm{~m}^{-3}(50 \mathrm{~m})^{-1}$ \\
\hline Surface stratification (temperature) & CTD & ${ }^{\circ} \mathrm{C}(50 \mathrm{~m})^{-1}$ \\
\hline BML temperature & CTD & ${ }^{\circ} \mathrm{C}$ \\
\hline BML salinity & CTD & PSU \\
\hline BML density (sigma-t) & CTD & sigma-t units $\left(\mathrm{kg} \mathrm{m}^{-3}\right)$ \\
\hline BML depth & CTD & $\mathrm{m}$ \\
\hline Depth of peak Calanus finmarchicus C5 abundance & OPC & $\mathrm{m}$ \\
\hline Peak C. finmarchicus C5 abundance & $\mathrm{OPC}$ & copepods $\mathrm{m}^{-3}$ \\
\hline Average water column C. finmarchicus C5 abundance & $\mathrm{OPC}$ & copepods $\mathrm{m}^{-3}$ \\
\hline C. finmarchicus $\mathrm{C} 5$ abundance above BML & $\mathrm{OPC}$ & copepods $\mathrm{m}^{-3}$ \\
\hline SST & AVHRR & ${ }^{\circ} \mathrm{C}$ \\
\hline SST gradient & AVHRR & ${ }^{\circ} \mathrm{C} \mathrm{km}^{-1}$ \\
\hline Surface chlorophyll & SeaWiFS & $\mathrm{mg} \mathrm{m}^{-3}$ \\
\hline Surface chlorophyll gradient & SeaWiFS & $\mathrm{mg} \mathrm{m}^{-3} \mathrm{~km}^{-1}$ \\
\hline
\end{tabular}


which the density differed from the bottom density by $0.05 \mathrm{~kg} \mathrm{~m}^{-3}$. Since the BML is uniformly mixed, the temperature, salinity and density measured near the sea floor were considered to be representative of the BML hydrographic properties.

The depth of right whale feeding dives is strongly correlated with the depth of the maximum Calanus finmarchicus C5 abundance (Baumgartner \& Mate 2003), so this variable was computed from the OPC data and included in the analysis. Several measures of C. finmarchicus $\mathrm{C} 5$ abundance were also derived from the OPC, including the maximum $C$. finmarchicus $\mathrm{C} 5$ abundance observed in the water column, the average water column abundance and the abundance of $C$. finmarchicus $\mathrm{C} 5$ above the BML. The latter was computed over a depth stratum spanning $20 \mathrm{~m}$ above to $5 \mathrm{~m}$ below the BML depth. All abundances of $C$. finmarchicus $C 5(x)$ were transformed as $\log _{10}(x+1)$ prior to analysis.

Remotely sensed SST and surface chlorophyll concentration were examined both for their capacity to represent relevant oceanographic features and for their potential as easily acquired, synoptic datasets upon which predictive models of right whale distribution may be based. High horizontal SST and surface chlorophyll gradients can indicate the presence of ocean fronts, so derived gradient data were included in the analysis to assess whether right whales utilize ocean fronts as habitat, as suggested by Gaskin (1987).

Logistic regression. Since adjacent right whale sightings collected during the systematic surveys were not always expected to be independent of one another, associations between right whale presence and the environmental variables were investigated using logistic regression analysis. The response variable for each survey unit was coded as 1 if one or more right whales were sighted in that unit and 0 if no right whales were sighted (Fig. 2). The log-transformed odds in favor of sighting a right whale in a survey unit $(\eta)$, also known as the logit of the sighting probability $(\pi)$, was then modeled as a linear function of the independent variables $\left(\mathrm{V}_{\mathrm{i}}\right)$ as follows

$$
\eta=\operatorname{logit}(\pi)=\ln \left(\frac{\pi}{1-\pi}\right)=\beta_{0}+\sum_{i=1}^{p} \beta_{i} V_{i}
$$

where $\beta_{0}$ is the intercept, $\beta_{i}$ represents the model coefficients and $p$ is the number of independent variables in the model. The significance of model terms were assessed using drop-in-deviance (likelihood ratio) statistics $(D)$ generated from the fitted model and a reduced model that lacked the term or terms of interest. Wald-based z-tests can also be used to assess the significance of individual model terms, but these tests are not considered as accurate as the drop-in-deviance test (Ramsey \& Schafer 1997, Hosmer \& Lemeshow
2000). However, Wald-based $z$-tests were conducted when a drop-in-deviance test was inappropriate or to supplement the drop-in-deviance test results. Waldbased $95 \%$ confidence intervals (CI) are also reported.

Logistic regression assumes a linear relationship between logits and the independent variables, and this assumption was checked by replacing an environmental variable in a model with a 4-level factor representing 4 levels of the environmental variable's values. The model coefficients for the corresponding dummy variables (including 0 for the reference level) were plotted against the mid-point of the ranges represented by each of the 4 factor levels. There was little evidence of curvature in these plots, and for many variables (including all of the variables found to be significant in the analyses below), the relationship between sighting logits and the environmental variables was clearly linear. Thus, the assumption of linearity for this study was appropriate.

Analysis of sighting conditions. The probability of sighting a right whale is influenced by factors that may prevent a whale from being observed from the survey platform. These factors or sighting conditions include the sea state, atmospheric conditions affecting visibility (e.g. haze, fog) or reflection of the sunshine off the sea surface (i.e. glare). The effect of sighting conditions on sighting probabilities was examined with a logistic regression model that included sea state, visibility and glare fraction as independent variables. Sea state was assessed on the Beaufort scale; visibility was estimated as the maximum distance at which a large object at the sea surface could be seen and the glare fraction was defined as the proportion of the area scanned from -90 to $90^{\circ}$ relative to the bow that was obscured by glare.

Analysis of spatial variability. Associations between the spatial distribution of right whales and the environmental variables within each region were examined using logistic regression models that included terms to account for the sighting conditions and regional and annual variability in both sighting probabilities and environmental conditions. To account for regional variability, a single dummy variable representing the region was included in the model to account for regional differences in sighting probabilities, and a regional anomaly of an environmental variable was included to account for regional differences in that variable. In the case of SST, for example, the resulting model would be of the following form:

$\operatorname{logit}(\pi)=\beta_{0}+\beta_{1}(\mathrm{BOF})+\beta_{2}(\mathrm{SST}$ regional anomaly $)$

where $\mathrm{BOF}$ is a dummy variable with values indicating the lower Bay of Fundy (BOF = 1) or Roseway Basin $(\mathrm{BOF}=0)$ and the SST anomalies for a particular region were computed by subtracting the regional mean SST 
from all SST observations in that region. The coefficient $\beta_{2}$ in this model indicates the nature of the relationship between local spatial variability in right whale sighting probability and local spatial variability in SST.

However, interannual variability in both sighting probability and SST can confound the results obtained with the model in Eq. (2). To account for this source of variability, dummy variables representing year were included in the model to account for annual differences in sighting probabilities, and SST anomalies were determined by subtracting the mean SST over a region in a particular year from the observations in that region and year. The resulting model was of the following form:

$$
\begin{aligned}
\operatorname{logit}(\pi)= & \beta_{0}+\beta_{1}(\mathrm{BOF})+\beta_{2}(\mathrm{Y} 2000)+\beta_{3}(\mathrm{Y} 2001)+ \\
& \beta_{4}(\mathrm{BOF} \times \mathrm{Y} 2000)+\beta_{5}(\mathrm{BOF} \times \mathrm{Y} 2001)+ \\
& \beta_{6}(\mathrm{SST} \text { regional } / \text { annual anomaly })
\end{aligned}
$$

where Y2000 and Y2001 are dummy variables indicating the years $1999(\mathrm{Y} 2000=0, \mathrm{Y} 2001=0), 2000$ $(\mathrm{Y} 2000=1, \mathrm{Y} 2001=0)$ and $2001(\mathrm{Y} 2000=0, \mathrm{Y} 2001=1)$. As above, the coefficient $\beta_{6}$ in this model indicates the nature of the relationship between local spatial variability in right whale sighting probability and local spatial variability in SST where 'local' now refers to both space (within region) and time (within year). Models of the form in Eq. (3) were fitted for each of the environmental variables. Additional terms to account for variations in sighting probabilities due to sighting conditions were included when warranted.

Finally, it is possible that the nature of the relationship between local spatial variability in sighting probability and an environmental variable may differ between regions. For example, right whale sighting probability may increase with SST in the lower Bay of Fundy, but may decrease with SST in Roseway Basin. To detect this situation, a model including an interaction term for the region and the environmental variable was fitted. This model is of the form:

$$
\begin{aligned}
\operatorname{logit}(\pi)= & \beta_{0}+\beta_{1}(\mathrm{BOF})+\beta_{2}(\mathrm{Y} 2000)+\beta_{3}(\mathrm{Y} 2001)+ \\
& \beta_{4}(\mathrm{BOF} \times \mathrm{Y} 2000)+\beta_{5}(\mathrm{BOF} \times \mathrm{Y} 2001)+ \\
& \beta_{6}(\mathrm{SST} \text { regional } / \text { annual anomaly })+ \\
& \beta_{7}(\mathrm{BOF} \times \mathrm{SST} \text { regional/annual anomaly })
\end{aligned}
$$

A significant drop-in-deviance test of the interaction term (the term involving $\beta_{7}$ ) provides evidence of an inter-regional difference in the association between sighting probability and SST. The sum of $\beta_{6}$ and $\beta_{7}$ indicates the nature of the relationship between sighting probability and SST in the lower Bay of Fundy $(\mathrm{BOF}=1)$ whereas $\beta_{6}$ alone indicates the nature of this relationship in Roseway Basin $(\mathrm{BOF}=0)$.

Overfitting is a major concern when applying logistic regression models to data containing rare events. Hosmer \& Lemeshow (2000) informally suggest that there should be at least 10 events per model parameter (in this study, an event is a survey unit with one or more right whales sighted). The model described in Eq. (3) contains 7 parameters and would therefore require at least 70 survey units with right whale sightings to satisfy these conditions. We observed only 29 units with right whales present. To investigate the effect of this low number of events, the models of the form in equation 3 were refitted without accounting for regional or interannual variability in sighting probabilities. These parsimonious models were of the following form (shown for SST and excluding terms to account for sighting conditions):

$\operatorname{logit}(\pi)=\beta_{0}+\beta_{1}(\mathrm{SST}$ regional/annual anomaly)

The resulting coefficients and drop-in-deviance tests from these models were compared to the corresponding models of the form in Eq. (3). Substantial differences in these coefficients and test results would indicate overfitting is a concern.

Analysis of interannual variability. Logistic regression was also used to investigate the environmental factors associated with interannual variability in sighting probabilities. However, since this study consists of only $3 \mathrm{yr}$ of data, we consider any such associations to represent tentative trends only. The regression analysis was confined to survey units in which interannual variability actually occurred (i.e. survey units in which no right whales were ever encountered and survey units in which right whales were encountered in every year of the study were excluded). Data from the lower Bay of Fundy for this analysis consisted of surveys in August of 1999, 2000 and 2001 only (i.e. the July 2000 survey was excluded). It is impossible to account for spatial variability in the sighting probabilities in a similar manner as the interannual variability in sighting probabilities was taken into account in the analysis of spatial distribution described above. However, limiting the analysis to only those survey units in which interannual variability occurred reduces the confounding due to this source of variability. Spatial variability in the environmental variables was taken into account by using temporal anomalies as independent variables in the models. These anomalies were determined by subtracting the $3 \mathrm{yr}$ mean of an environmental variable within a single survey unit from each of the observations in that survey unit. The resulting logistic regression model took the following form (excluding terms to account for sighting conditions):

$$
\operatorname{logit}(\pi)=\beta_{0}+\beta_{1}\left(V_{\mathrm{T}}\right)
$$

where $V_{\mathrm{T}}$ denotes the temporal anomaly of an environmental variable and $\beta_{1}$ indicates the nature of the association between the interannual variability in sighting probabilities and the interannual variability in the environmental variable of interest. Inter-regional differ- 
ences in the association between sighting probability and the environmental variables were also investigated using the following model (excluding terms to account for sighting conditions):

$\operatorname{logit}(\pi)=\beta_{0}+\beta_{1}\left(V_{\mathrm{T}}\right)+\beta_{2}(\mathrm{BOF})+\beta_{3}\left(\mathrm{BOF} \times V_{\mathrm{T}}\right)$

A drop-in-deviance statistic was computed from a reduced model that lacked the last 2 terms in Eq. (7). A significant drop-in-deviance statistic suggested that the association between sighting probability and $V_{\mathrm{T}}$ was different between the lower Bay of Fundy and Roseway Basin.

\section{RESULTS}

\section{Zooplankton sampling}

Calanus finmarchicus $\mathrm{C} 5$ dominated the zooplankton community near right whales. The proportion of $C$. finmarchicus $\mathrm{C} 5$ to all copepods was significantly higher in samples collected near right whales than in samples collected in the absence of right whales (333 $\mu \mathrm{m}$ mesh bongo tows only, 2-sample $t$-test after arcsine transformation, $t=4.21, \mathrm{p}=0.0003$ ). No other copepod species or copepodite stage of $C$. finmarchicus exhibited a similar dominance. The percent composition of $C$. finmarchicus $\mathrm{C} 5$ averaged $67 \%$ near right whales $(\mathrm{n}=12)$ and ranged as high as $92 \%$ in the lower Bay of Fundy, whereas the percent composition of $C$. finmarchicus $\mathrm{C} 5$ collected in the absence of right whales averaged only
$26 \%$ (n = 14). The abundance of $C$. finmarchicus C5 was also significantly higher in samples collected near right whales than in samples collected in the absence of right whales (333 $\mu \mathrm{m}$ mesh bongo tows only, 2 -sample $t$-test, $t=6.29, \mathrm{p}<0.0001)$. Only $C$. finmarchicus adults $(\mathrm{p}=0.0034)$ and Calanus glacialis $(\mathrm{p}=0.014)$ exhibited a similar significant trend in abundance, but $C$. finmarchicus $\mathrm{C} 5$ was an average 20 and 35 times more abundant than C. finmarchicus adults and C. glacialis, respectively, in samples collected near right whales.

Zooplankton sampling in the lower Bay of Fundy indicated that Calanus finmarchicus $\mathrm{C} 5$ average water column abundance near right whales decreased from 1145 copepods $\mathrm{m}^{-3}$ in $1999(\mathrm{n}=7, \mathrm{SD}=322,95 \% \mathrm{CI}$ : $848-1443$ ) to 457 copepods $\mathrm{m}^{-3}$ in $2000(\mathrm{n}=3, \mathrm{SD}=74$, $95 \%$ CI: $273-640)$ and 505 copepods $\mathrm{m}^{-3}$ in $2001(\mathrm{n}=$ $6, \mathrm{SD}=186,95 \%$ CI: $311-700$ ) (Fig. 3). The respective 2.5- and 2.3-fold decreases in the average C. finmarchicus C5 abundance from 1999 to 2000 and from 1999 to 2001 in the lower Bay of Fundy were coincident with estimated 4.8-fold (95\% CI: $1.1-20$ ) and 6.8-fold (95\% CI: $1.1-42)$ decreases in the odds of sighting a right whale in a lower Bay of Fundy survey unit over these same time periods. Although only 2 zooplankton samples were collected near right whales in Roseway Basin, the net samples and OPC data suggest that average water column abundance of $C$. finmarchicus C5 either near right whales or in survey units where whales were present increased from 1999 to 2001 (Fig. 3). Interestingly, the OPC-derived average water column abundance of C. finmarchicus C5 in survey

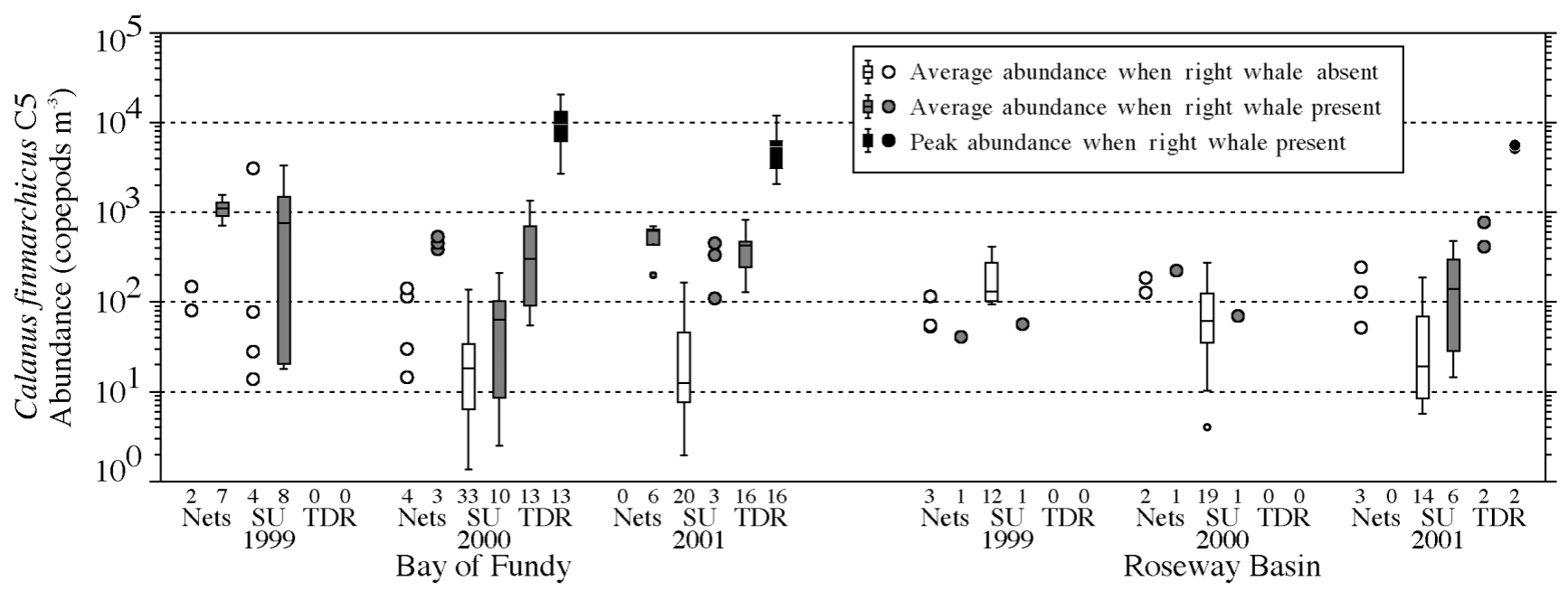

Fig. 3. Eubalaena glacialis and Calanus finmarchicus. Distribution of C. finmarchicus C5 abundance derived from zooplankton samples (Nets), optical plankton counter (OPC) casts conducted in the middle of each survey unit (SU) and OPC casts conducted near whales tagged with time-depth recorders (TDR) for each region and year. Average water column abundances in areas or survey units where right whales were absent or present are indicated as either boxplots (for $n>4$ ) or large circles (for $n \leq 4$ ). The peak water column abundance observed near tagged right whales is indicated as either black histograms or filled black circles $(\bullet)$. Sample sizes for each distribution are shown just below the lower $x$ axis. Sample sizes for abundances associated with tagged whales indicate the number of tagged whales for which a single, average $C$. finmarchicus C5 abundance was computed.

Data for tagged whales are from Baumgartner \& Mate (2003) 
units where right whales were absent actually decreased over this same time period (Fig. 3).

A spatial trend in OPC-derived Calanus finmarchicus C5 abundance in proximity to right whales is apparent during years when sample sizes were sufficient (2000 and 2001 in the lower Bay of Fundy and during 2001 in Roseway Basin). C. finmarchicus C5 abundance increased as the distance to a right whale decreased (i.e. from survey units with right whales absent to survey units with right whales present and finally to within a few hundred meters of a right whale) (Fig. 3). OPC casts conducted along the track of right whales that were tagged with time-depth recorders (Baumgartner \& Mate 2003) indicated that average water column abundance of $C$. finmarchicus C5 was roughly an order of magnitude higher near right whales (<300 $\mathrm{m}$ away) than in areas where right whales were absent. Baumgartner \& Mate (2003) found strong evidence to suggest that right whales feed at the depth of maximum C. finmarchicus C5 abundance. The abundance at this depth is at least an order of magnitude higher still than the average water column abundance of C. finmarchicus C5 observed near right whales. The net-derived abundances of $C$. finmarchicus C5 obtained near right whales in the lower Bay of Fundy during 2000 and 2001 corroborate the corresponding, but independent OPC-derived average water column abundances obtained near tagged whales (Fig. 3).

\section{Sighting conditions}

There was no evidence to suggest that the probability of sighting 1 or more right whales in a survey unit was associated with either visibility $(D=1.91$, $\mathrm{df}=1, \mathrm{p}=0.17)$ or glare fraction $(D=0.293, \mathrm{df}=1, \mathrm{p}=$ 0.59). The potential impacts of both of these factors were largely controlled in the field by halting surveys when visibility was reduced to below $3.7 \mathrm{~km}$ ( $2 \mathrm{n}$ miles) and by running survey transects in a direction opposite the sun when possible (i.e. to the west in the morning and to the east in the afternoon). There was, however, evidence to suggest an effect of sea state on the probability of sighting $(D=6.166, \mathrm{df}=1, \mathrm{p}=0.013)$, and the resulting logistic regression model indicated that the odds of sighting a right whale changed by a factor of 0.628 (95\% CI: $0.428-0.921)$ for every unit increase in Beaufort sea state. Due to the significance of this effect, sea state was included in all subsequent logistic regression models.

\section{Regional trends in sighting probabilities}

Relative abundance and point estimates of sighting probability declined in the lower Bay of Fundy from 1999 to 2001, while relative abundance in Roseway Basin increased (Table 2). The odds of sighting a right whale decreased significantly from 1999 to 2000 in the lower Bay of Fundy (Wald-based $z$-test, $p=0.033$ ), but there was no evidence of a change from 2000 to 2001 $(p=0.64)$. There was no evidence of a change in the odds of sighting a right whale from 1999 to 2000 in Roseway Basin ( $p=0.31$ ); however, these odds increased significantly from 2000 to 2001 ( $p=0.037$ ). There was no evidence that the odds of sighting a right whale were different in the lower Bay of Fundy and Roseway Basin in 1999 (Wald-based $z$-test, $\mathrm{p}=0.093$ ) or $2001(p=0.54)$, although the sample size in 1999 was small (Table 2). The odds of sighting a right whale in

Table 2. Eubalaena glacialis. Location and dates of surveys. Average sea state during each survey is reported on the Beaufort scale and relative abundance is reported as the number of right whales sighted per $10 \mathrm{~km}$ of transect searched. The probability of sighting at least 1 right whale in a survey unit and the corresponding $95 \%$ confidence interval (CI) were estimated after accounting for the effect of sea state. Note that the Bay of Fundy survey transects were searched twice during 2000

\begin{tabular}{|c|c|c|c|c|c|c|c|}
\hline $\begin{array}{l}\text { Location } \\
\text { Year }\end{array}$ & Dates & $\begin{array}{l}\text { Average } \\
\text { sea state }\end{array}$ & $\begin{array}{l}\text { No. units } \\
\text { sampled }\end{array}$ & $\begin{array}{c}\text { No. units } \\
\text { with whales }\end{array}$ & $\begin{array}{l}\text { Probability } \\
\text { of sighting }^{a}\end{array}$ & $\begin{array}{c}\text { Wald's } \\
95 \% \text { CI }^{a}\end{array}$ & $\begin{array}{l}\text { Relative } \\
\text { abundance }\end{array}$ \\
\hline \multicolumn{8}{|c|}{ Bay of Fundy } \\
\hline 1999 & 19 Aug & 2.2 & 12 & 8 & 0.58 & $0.28-0.83$ & 5.2 \\
\hline 2000 & 20-22 Jul, 20-23 Aug & 3.0 & 43 & 10 & 0.22 & $0.12-0.37$ & 1.9 \\
\hline 2001 & 9-27 Aug & 3.9 & 23 & 3 & 0.17 & $0.05-0.42$ & 0.5 \\
\hline \multicolumn{8}{|c|}{ Roseway Basin } \\
\hline 1999 & 30-31 Aug & 4.4 & 13 & 1 & 0.13 & $0.02-0.57$ & 0.1 \\
\hline 2000 & 23-26 Jul & 2.0 & 20 & 1 & 0.03 & $0.00-0.20$ & 0.5 \\
\hline 2001 & 24-26 Jul & 2.6 & 20 & 6 & 0.25 & $0.11-0.49$ & 1.0 \\
\hline \multicolumn{8}{|c|}{$\begin{array}{l}\text { Estimated from logistic regression models with a reference level corresponding to the region and year of interest and a } 3.0 \\
\text { Beaufort sea state, e.g. the log-odds of the sighting probability for Roseway Basin in } 2000 \text { at a Beaufort sea state of } 3.0 \\
\text { was estimated to be } \beta_{0} \text { in the following model: logit }(\pi)=\beta_{0}+\beta_{1}(\text { Sea state }-3.0)+\beta_{2}(\mathrm{BOF})+\beta_{3}(\mathrm{Y} 1999)+\beta_{4}(\mathrm{Y} 2001)+ \\
\beta_{5}(\mathrm{BOF} \times \mathrm{Y} 1999)+\beta_{6}(\mathrm{BOF} \times \text { Y2001), where BOF is a dummy variable indicating region (lower Bay of Fundy, BOF }=1 \text {; } \\
\text { Roseway Basin, BOF }=0) \text {, and Y1999 and Y2001 are dummy variables indicating the years } 1999 \text { and 2001, respectively }\end{array}$} \\
\hline
\end{tabular}


the Bay of Fundy were 9.44 (95\% CI: 1.05 - 84.9) times higher than in Roseway Basin in 2000 ( $p=0.045$ ). These results support the use of dummy variables in the subsequent spatial models to account for interannual and inter-regional differences in sighting probabilities.

\section{Spatial variability}

There was strong evidence that within-region and within-year spatial variability in sighting probability was associated with spatial variability in depth, the depth of maximum Calanus finmarchicus C5 abundance, BML density, BML salinity, maximum water column C. finmarchicus C5 abundance, average water column abundance of $C$. finmarchicus C5, BML depth and the $C$. finmarchicus $\mathrm{C} 5$ abundance above the BML (Table 3). The most significant association detected was between sighting probability and depth $(D=$ 19.54 , df $=1, \mathrm{p}<0.0001$ ). All of the other variables with which sighting probability was significantly associated were correlated with depth (Table 3). There was also evidence of inter-regional differences in the association between sighting probability and BML temperature, SST gradient and surface chlorophyll gradient. Wald-based $z$-test results suggest right whale sighting probability decreased significantly with increasing BML temperature in the lower Bay of Fundy; however, this variable was also correlated with depth in this region $(r=-0.549, \mathrm{p}<0.0001)$. The model that included depth as an independent variable (without a regional interaction term) indicated that the odds of sighting a right whale increased by a factor of 1.42 (95\% CI: 1.19 - 1.69) for every $10 \mathrm{~m}$ increase in water depth.

Because of the apparent importance of water depth, a second group of models was investigated with depth as an additional independent variable (Table 4). Of the variables included in these models, only BML depth was found to be significant $(D=5.61, \mathrm{df}=1, \mathrm{p}=0.018$ ). However, these results may be confounded by multicollinearity owing to the strong correlation between depth and some of the other environmental variables

Table 3. Eubalaena glacialis. Test results for each environmental variable in the logistic regression analysis of spatial variability. Drop-in-deviance statistics $(D)$, associated p-values (p) and the model coefficients (Coeff) are reported for models with and without an interaction term to account for inter-regional differences in the association between sighting probability and the environmental variable. Environmental variables were included in the models as anomalies from regional/annual means. Correlation coefficients reported for comparisons between regional/annual anomalies of depth and all other environmental variables. Prey abundance refers to that of Calanus finmarchicus C5. All drop-in-deviance statistics have 1 degree of freedom. $p=0.0000$ indicates $p<0.00005$ and $p=1.00$ indicates $p \geq 0.995$. Significance: ${ }^{*} 0.05>p \geq 0.01,{ }^{* *} 0.01>p \geq 0.001,{ }^{* * *} p<0.001$. Abbreviations as in previous tables

\begin{tabular}{|c|c|c|c|c|c|c|c|c|}
\hline \multirow{2}{*}{ Variable } & \multirow{2}{*}{$\begin{array}{l}\text { Correlation } \\
\text { with depth }\end{array}$} & \multicolumn{3}{|c|}{ Single variable model ${ }^{\mathrm{a}}$} & \multicolumn{4}{|c|}{ Model allowing inter-regional difference ${ }^{b}$} \\
\hline & & $D$ & $\mathrm{p}$ & Coeff & $D$ & $\mathrm{p}$ & $\begin{array}{l}\text { Fundy } \\
\text { Coeff }\end{array}$ & $\begin{array}{c}\text { Roseway } \\
\text { Coeff }\end{array}$ \\
\hline Depth & - & $19.54^{* * *}$ & 0.0000 & 0.0351 & 0.03 & 0.86 & & \\
\hline Depth gradient & $-0.280^{* *}$ & 0.50 & 0.48 & -0.0452 & 0.20 & 0.65 & & \\
\hline Surface stratification (density) & -0.072 & 0.39 & 0.53 & -0.396 & 0.22 & 0.64 & & \\
\hline $\begin{array}{l}\text { Surface stratification } \\
\text { (temperature) }\end{array}$ & 0.060 & 0.01 & 0.93 & -0.0137 & 0.00 & 1.00 & & \\
\hline BML temperature & $-0.222^{*}$ & 1.59 & 0.21 & -0.592 & $9.55^{* *}$ & 0.0020 & $-4.00^{*}$ & 0.329 \\
\hline BML salinity & $0.761^{* * *}$ & $12.99^{* * *}$ & 0.0003 & 3.57 & 0.37 & 0.54 & & \\
\hline BML density & $0.783^{* * *}$ & $14.96^{* * *}$ & 0.0001 & 4.71 & 0.01 & 0.93 & & \\
\hline BML depth & $0.868^{* * *}$ & $7.26^{* *}$ & 0.0070 & 0.0219 & 0.01 & 0.94 & & \\
\hline Depth of peak prey abundance & $0.749^{* * *}$ & $15.54^{* * *}$ & 0.0001 & 0.0340 & 2.00 & 0.16 & & \\
\hline Peak prey abundance & $0.537^{* * *}$ & $11.58^{* * *}$ & 0.0007 & 1.65 & 1.37 & 0.24 & & \\
\hline $\begin{array}{l}\text { Average water column prey } \\
\text { abundance }\end{array}$ & $0.412^{* * *}$ & $8.01^{* *}$ & 0.0047 & 1.21 & 0.00 & 0.97 & & \\
\hline Prey abundance above BML & $0.388^{* * *}$ & $3.97^{*}$ & 0.046 & 0.625 & 0.05 & 0.82 & & \\
\hline SST & 0.055 & 0.01 & 0.94 & -0.0309 & 0.37 & 0.54 & & \\
\hline SST gradient & -0.057 & 0.93 & 0.34 & 4.47 & $5.43^{*}$ & 0.020 & -7.24 & $16.4^{*}$ \\
\hline Surface chlorophyll & -0.138 & 2.22 & 0.14 & -0.660 & 3.66 & 0.056 & & \\
\hline Surface chlorophyll gradient & -0.113 & 1.61 & 0.20 & 4.34 & $7.19^{* *}$ & 0.0073 & -6.16 & $56.3^{*}$ \\
\hline \multicolumn{9}{|c|}{$\begin{array}{l}\left.{ }^{a} \text { Model (Eq. 3): } \operatorname{logit}(\pi)=\beta_{0}+\beta_{1} \text { (Sea state }\right)+\beta_{2}(\mathrm{BOF})+\beta_{3}(\mathrm{Y} 2000)+\beta_{4}(\mathrm{Y} 2001)+\beta_{5}(\mathrm{BOF} \times \mathrm{Y} 2000)+\beta_{6}(\mathrm{BOF} \times \mathrm{Y} 2001)+ \\
\beta_{7} \text { (Variable). Drop-in-deviance test }(D, \mathrm{p}) \text { and estimated coefficient }\left(\text { Coeff) reported for the term involving } \beta_{7}\right. \\
\left.{ }^{\mathrm{b}} \text { Model (Eq. } 4\right) \text { : logit }(\pi)=\beta_{0}+\beta_{1}(\text { Sea state })+\beta_{2}(\mathrm{BOF})+\beta_{3}(\mathrm{Y} 2000)+\beta_{4}(\mathrm{Y} 2001)+\beta_{5}(\mathrm{BOF} \times \mathrm{Y} 2000)+\beta_{6}(\mathrm{BOF} \times \mathrm{Y} 2001)+ \\
\beta_{7} \text { (Variable) }+\beta_{8}(\mathrm{BOF} \times \text { Variable }) \text {. Drop-in-deviance test }(D, \mathrm{p}) \text { reported for the term involving } \beta_{8} \text {. Estimated coefficients } \\
\text { (Coeff) are }\left(\beta_{7}+\beta_{8}\right) \text { and } \beta_{7} \text { for the lower Bay of Fundy and Roseway Basin, respectively. Only coefficients for models with a } \\
\text { significant interaction term are shown. Wald-based significance of these coefficients indicated with asterisks }\end{array}$} \\
\hline
\end{tabular}


Table 4. Eubalaena glacialis. Test results for each environmental variable in the logistic regression analysis of spatial variability after accounting for the influence of depth on sighting probabilities. Because multicollinearity may be a problem for these analyses (Table 3), uncorrelated variables (principal components, PCs) were created from a PC analysis of depth and an environmental variable. Results are shown for models that use these PCs as independent variables. PC1 was always significant in these models ( $p<0.001$ ), so drop-in-deviance statistics are shown for PC2 only. Abbreviations as in previous tables; significance as in Table 3

\begin{tabular}{|c|c|c|c|c|c|}
\hline \multirow[b]{2}{*}{ Variable } & \multicolumn{3}{|c|}{ Model including depth ${ }^{\mathrm{a}}$} & \multicolumn{2}{|c|}{ Model with PCs ${ }^{\mathrm{b}}$} \\
\hline & $D$ & $\mathrm{p}$ & Coeff & $D$ & $\mathrm{p}$ \\
\hline Depth & - & - & - & - & - \\
\hline Depth gradient & 0.01 & 0.92 & 0.00867 & 0.01 & 0.91 \\
\hline Surface stratification (density) & 0.01 & 0.94 & -0.0575 & 0.01 & 0.94 \\
\hline Surface stratification (temperature) & 0.00 & 0.97 & 0.00750 & 0.00 & 0.97 \\
\hline BML temperature & 0.07 & 0.79 & -0.162 & 0.07 & 0.79 \\
\hline BML salinity & 0.01 & 0.91 & 0.184 & 0.01 & 0.91 \\
\hline BML density & 0.08 & 0.77 & 0.654 & 0.08 & 0.77 \\
\hline BML depth & $5.61^{*}$ & 0.018 & -0.0413 & $10.99^{* * *}$ & 0.0009 \\
\hline Depth of peak prey abundance & 1.21 & 0.27 & 0.0144 & 0.25 & 0.62 \\
\hline Peak prey abundance & 1.93 & 0.16 & 0.847 & 1.93 & 0.16 \\
\hline $\begin{array}{l}\text { Average water column prey } \\
\text { abundance }\end{array}$ & 0.99 & 0.32 & 0.501 & 0.98 & 0.32 \\
\hline Prey abundance above BML & 0.18 & 0.67 & 0.153 & 0.18 & 0.67 \\
\hline SST & 0.01 & 0.92 & -0.0402 & 0.01 & 0.92 \\
\hline SST gradient & 2.10 & 0.15 & 8.01 & 2.10 & 0.15 \\
\hline Surface chlorophyll & 1.17 & 0.28 & -0.518 & 1.17 & 0.28 \\
\hline Surface chlorophyll gradient & 0.83 & 0.36 & -3.51 & 0.83 & 0.36 \\
\hline \multicolumn{6}{|c|}{ 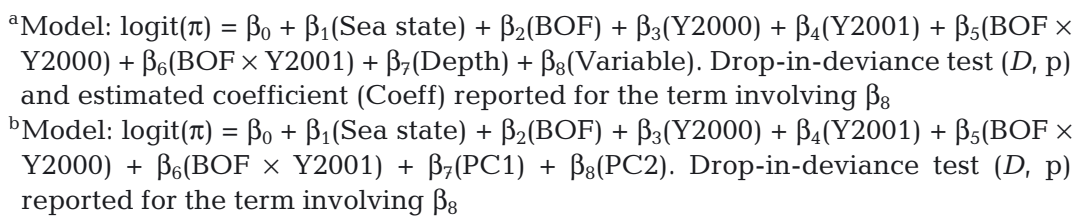 } \\
\hline
\end{tabular}

Table 5. Eubalaena glacialis. Logistic regression model of spatial variability with depth and BML depth anomalies ( $\mathrm{n}=131$ survey units, 29 units with right whales present $)$. Residual deviance $=90.39(\mathrm{df}=122)$, null deviance $=138.50(\mathrm{df}=130)$ and overall drop-in-deviance $=48.11(\mathrm{df}=8, \mathrm{p}<0.0001)$. Abbreviations as in previous tables; significance as in Table 3

\begin{tabular}{|c|c|c|c|c|c|c|c|}
\hline Term & Coeff & $\mathrm{SE}$ & $\begin{array}{c}\text { Wald } \\
\text { z-statistic }\end{array}$ & $\mathrm{p}$ & $\begin{array}{l}\text { Drop in } \\
\text { deviance }\end{array}$ & $\mathrm{df}$ & $\mathrm{p}$ \\
\hline Intercept & 1.14 & 1.75 & 0.65 & 0.51 & & & \\
\hline Sea state & -0.871 & 0.330 & $-2.64^{* *}$ & 0.0083 & $8.15^{* *}$ & 1 & 0.0043 \\
\hline Region $^{a}$ & & & & & $10.24^{*}$ & 3 & 0.017 \\
\hline BOF & 1.70 & 1.46 & 1.17 & 0.24 & & & \\
\hline Year $^{\mathrm{a}}$ & & & & & $15.42^{* *}$ & 4 & 0.0039 \\
\hline Y2000 & -2.80 & 1.75 & -1.60 & 0.11 & & & \\
\hline Y2001 & -0.00422 & 1.36 & 0.00 & 1.00 & & & \\
\hline Region $\times$ Year & & & & & $6.52^{*}$ & 2 & 0.038 \\
\hline $\mathrm{BOF} \times \mathrm{Y} 2000$ & 0.808 & 2.03 & 0.40 & 0.69 & & & \\
\hline $\mathrm{BOF} \times \mathrm{Y} 2001$ & -2.53 & 1.89 & -1.33 & 0.18 & & & \\
\hline Depth & 0.0708 & 0.0193 & $3.67^{* * *}$ & 0.0002 & $17.88^{* * *}$ & 1 & 0.0000 \\
\hline BML depth & -0.0413 & 0.0179 & $-2.31^{*}$ & 0.021 & $5.61^{*}$ & 1 & 0.018 \\
\hline
\end{tabular}

(Table 3). Therefore, another set of models was examined where the 2 independent variables in a model were the 2 uncorrelated principal components (PC) from a principal components analysis of depth and an environmental variable (Table 4). The first PC was significant $(p<0.001)$ in all of these models, but the second PC was only significant in the model using principal components constructed from depth and BML depth $(D=10.99$, df $=1, \mathrm{p}=$ 0.0009). Since each of these analyses (using the raw environmental variables and using the PCs) yielded similar results (Table 4), we conclude that multicollinearity was not problematic. The model with depth and BML depth as the independent variables (without the PC analysis) indicated that the odds of sighting a right whale increased by a factor of $1.51 \quad(95 \% \quad \mathrm{CI}$ : 1.06 - 2.14) for every $10 \mathrm{~m}$ decrease in the BML depth after accounting for the effect of water depth (Table 5).

To verify that no other combination of variables produced a more significant model than the one reported in Table 5, models were constructed with sea state, dummy variables for region and year (with interactions) and all possible combinations of 1 or 2 environmental variables $(\mathrm{n}=136$ models). A reduced model with only sea state and dummy variables for region and year (with interactions) was used to generate drop-in-deviance statistics. The models with depth alone and both depth and BML depth were ranked well above all other models when ordered by the significance of the drop-in-deviance test. Parsimonious versions of the models shown in Tables 3 \& 4 were fitted with only sea state and 1 or 2 of the environmental variables to investigate the potential effect of overfitting (see 
Table 7. Eubalaena glacialis. Logistic regression model of interannual variability with SST anomaly ( $\mathrm{n}=27$ survey units, 10 units with right whales present). Residual deviance $=18.33$ $(\mathrm{df}=24)$, null deviance $=35.59(\mathrm{df}=26)$ and overall drop-indeviance $=17.26(\mathrm{df}=2, \mathrm{p}=0.0002)$. Abbreviations as in previous tables; significance as in Table 3

\begin{tabular}{|lllclllll|}
\hline Term & Coeff & SE & $\begin{array}{c}\text { Wald } \\
\text { z-statistic }\end{array}$ & p & $\begin{array}{c}\text { Drop in } \\
\text { deviance }\end{array}$ & df & $p$ \\
\hline Intercept & 1.68 & 1.30 & 1.29 & 0.20 & & & \\
Sea state & -0.928 & 0.508 & -1.83 & 0.068 & $4.66^{*}$ & 1 & 0.031 \\
SST & -1.16 & 0.533 & $-2.18^{*}$ & 0.030 & $7.07^{* *}$ & 1 & 0.0079 \\
\hline
\end{tabular}

Woodley \& Gaskin (1996) and Stone et al. (1988), indicating that right whales feed on Calanus finmarchicus C5 in the lower Bay of Fundy and Roseway Basin. Younger stages of $C$. finmarchicus caught by the bongo nets ( $\mathrm{C} 3$ and $\mathrm{C} 4)$ did not exhibit similar trends in dominance or abundance as did C. finmarchicus $\mathrm{C} 5$ near right whales, and adult $C$. finmarchicus were always much less abundant than C. finmarchicus C5. The depth stratified samples, collected with the MOCNESS in the lower Bay of Fundy during 2001, confirm the existence of deep layers of C. finmarchicus C5 observed by Murison \& Gaskin (1989) and Baumgartner \& Mate (2003). These layers are likely composed of animals in diapause because of their deep distribution, stage composition, empty guts, large oil sacs and low activity levels (Baumgartner et al. 2003 this issue). Similar discrete aggregations of C. finmarchicus C5 were observed near right whales in Roseway Basin during 2001 (Baumgartner \& Mate 2003).

It is interesting, then, that the Calanus finmarchicus C5 abundance variables did not emerge as the most important factors in the analyses of either spatial or interannual variability in right whale occurrence. This is likely a consequence of the sampling methodology. The C. finmarchicus C5 abundance variables were derived from OPC casts conducted in the center of each survey unit. Since C. finmarchicus C5 average water column abundances for these casts were typically lower than those observed near tagged whales (Fig. 3), we infer that C. finmarchicus C5 abundance varied on short spatial scales (i.e. copepod patch sizes were small relative to the size of a survey unit). The spatial scales of variation for the physiographic and physical oceanographic variables were expected to be significantly larger. Therefore, the $C$. finmarchicus C5 abundance measured at the station in the center of a survey unit was not always representative of the abundance near right whales in that unit, whereas the corresponding physical observations at the station were probably representative of conditions over most of the survey unit. Since this less ecologically relevant measurement of $C$. finmarchicus C5 abundance was included in the logistic regression analyses, the strength of the association between right whales and C. finmarchicus $\mathrm{C} 5$ abundance was probably obscured.

The correlation between average water column abundance of Calanus finmarchicus C5 and water depth suggests that the deepest parts of both Roseway Basin and Grand Manan Basin in the lower Bay of Fundy are sites of closed circulation that passively aggregate and retain diapausing $C$. finmarchicus C5. These deep regions thus provide the best foraging grounds within each region, which accounts for the higher probability of sighting right whales in deeper waters. Woodley \& Gaskin (1996) also found that right whales utilize the deeper areas of the lower Bay of Fundy and invoked a similar explanation for the accumulation of $C$. finmarchicus. The baroclinic (densitydriven) component of the flow in these basins can be estimated from the hydrographic data obtained in this study, but the residual barotropic or depth-independent flow (generated primarily by the tides and an important constituent of the mean currents in these regions) cannot be quantified easily using ship-based methods (Greenberg 1983). Hence, it is difficult to demonstrate that gyres existed in these basins during the study. The existence of a cyclonic gyre in Grand Manan Basin has been inferred, however, from both surface (Fish \& Johnson 1937, Hachey \& Bailey 1952 cited in Bumpus 1960, Godin 1968 cited in Greenberg 1983) and bottom (Lauzier 1967) observations and corroborated in ocean model studies (Lynch et al. 1996, Xue et al. 2000). Lynch et al. (1996) suggest that tidal rectification produces this gyre. We conducted an unintended drifter experiment in Grand Manan Basin during the summer of 2000 by failing to immediately recover an archival tag that had been attached to a right whale for a foraging ecology study (Baumgartner $\&$ Mate 2003). The tag was relocated via radio telemetry $6.5 \mathrm{~d}$ later and only $10.5 \mathrm{~km}$ away from its last known location (net speed $=1.9 \mathrm{~cm} \mathrm{~s}^{-1}$ ). This fortunate recovery suggests that at least the surface circulation in Grand Manan Basin retains particles over weekly time scales. The importance of the barotropic component in the gyre suggests that this particle retention also occurs at depth (Greenberg 1983).

The probability of sighting a right whale was higher in waters with shallow BML depths after accounting for the effect of water depth on sighting probability. One possible explanation for this result is that a shallow BML depth promotes concentration of Calanus finmarchicus above it (Fig. 4b), whereas the vertical distribution of $C$. finmarchicus $C 5$ above a deep BML is more uniform (Fig. 4a); these conditions may arise if $C$. finmarchicus $\mathrm{C} 5$ actively avoid the upper layers of the water column, perhaps due to increased illumination 
Fig. 4. Prey availability scenario depicting (a) a deep bottom mixed layer (BML) depth without a discrete layer of Calanus finmarchicus C5 above the BML and (b) a shallow BML depth with a discrete layer above the BML. Horizontal lines indicate the sea surface, BML depth (dashed line), and sea floor (thick line). Vertical distribution of C. finmarchicus C5 is represented by dots
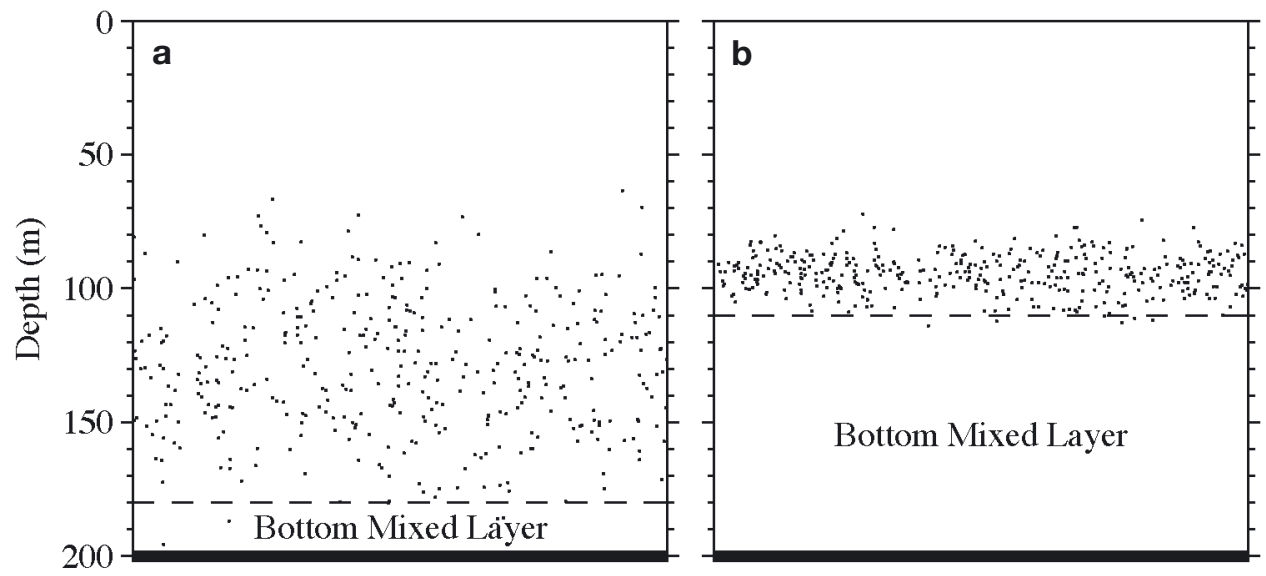

(and hence predation) or warmer temperatures. However, our observations suggest that this scenario does not occur. The abundance of $C$. finmarchicus $\mathrm{C} 5$ above the BML was positively correlated with BML depth ( $\mathrm{r}=$ $0.345, \mathrm{p}=0.0001$ ), which implies that $C$. finmarchicus C5 became more abundant or were more discretely concentrated as BML depth increased. A more plausible explanation, then, is that foraging on similar concentrations of $C$. finmarchicus C5 at shallow depths (Fig. 5b) rather than deep depths (Fig. 5a) affords a right whale more feeding time, and thus more energy can be acquired per dive for similar energy expenditure. For a constant total dive time, duration at depth can be extended by reducing transit times between the surface and the depth at which feeding occurs. This can be accomplished by increasing descent and ascent rates and by foraging at shallower depths. Baumgartner \& Mate (2003) provide evidence of the former and the present study suggests the latter. Using the average dive duration (12.2 $\mathrm{min})$, descent speed $\left(1.40 \mathrm{~m} \mathrm{~s}^{-1}\right)$ and ascent speed $\left(1.47 \mathrm{~m} \mathrm{~s}^{-1}\right)$ from Baumgartner \& Mate (2003) and the observed range of BML depths for waters of approximately $200 \mathrm{~m}$ depth in this study, we predict that right whales could extend their feeding time nearly $20 \%$ by foraging above a BML depth of $110 \mathrm{~m}$ (Fig. 5b) rather than foraging above a BML depth of $180 \mathrm{~m}$ (Fig. 5a).

Woodley \& Gaskin (1996) reported higher surface temperatures in lower Bay of Fundy areas where right whales were present than in areas without them, but we found no evidence of this. Although Murison \& Gaskin (1989) and Woodley \& Gaskin (1996) state that right whales in the lower Bay of Fundy tend to frequent waters of high surface stratification, we found no evidence of this when measurements of surface stratification were made and the association was statistically tested.

Gaskin (1987) suggested that the transition zone between tidally mixed and thermally stratified areas is a feature of right whale habitat in the lower Bay of Fundy and on the Scotian Shelf. Despite some supportive anecdotal evidence from Murison \& Gaskin (1989), neither they, Woodley \& Gaskin (1996) nor we found any quantitative evidence to support an association between right whales and ocean fronts in the lower Bay of Fundy. However, we did find an association between spatial variability in right whale occurrence in Roseway Basin and the 2 proxies for ocean fronts:
Fig. 5. Prey availability scenario depicting (a) a deep BML depth with a discrete layer above the BML and (b) a shallow BML depth with a discrete layer above the BML. Stereotypical right whale dive profiles with a constant dive time are superimposed. Horizontal axis represents time for the dive profiles. Lines and dots as in Fig. 4
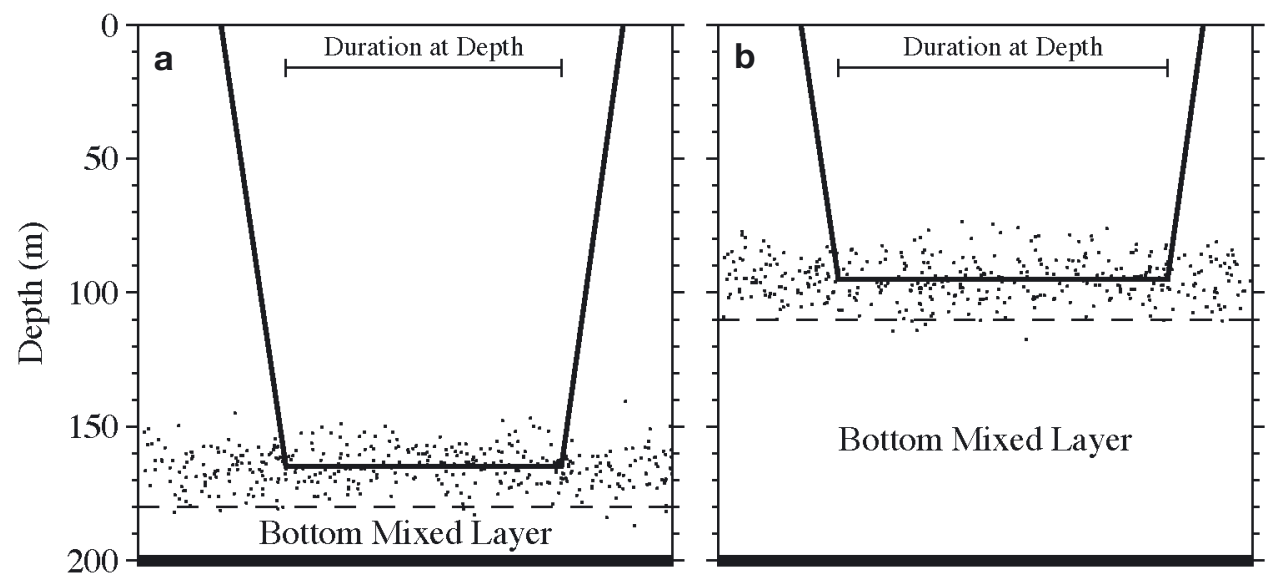
SST gradient and surface chlorophyll gradient. Furthermore, there was some indication that interannual variability in right whale occurrence in Roseway Basin might also be related to SST gradient (Table 6). As SST decreased in Roseway Basin from 1999 to 2001, the regional abundance of fronts increased (Fig. 6). These changes were accompanied by an increase in the occurrence of right whales in the survey region. At the

\section{a}
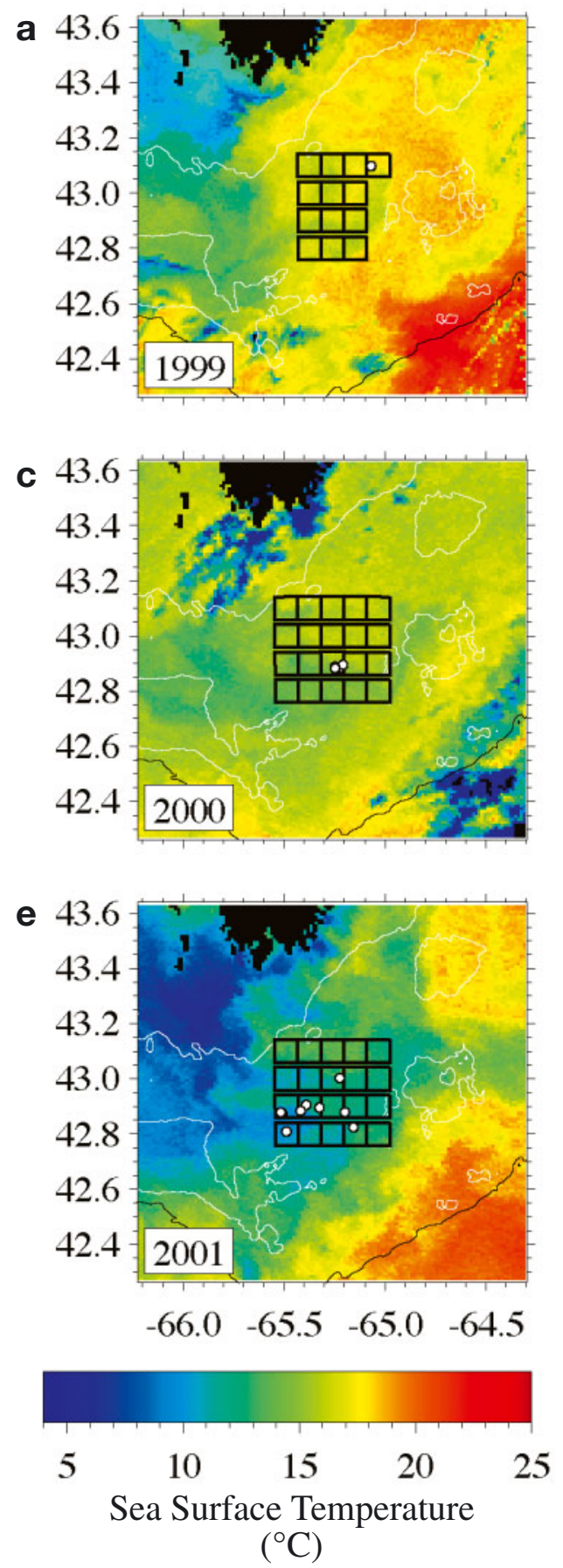

b

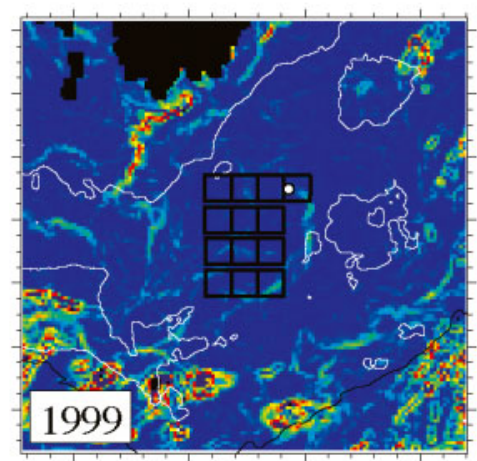

d

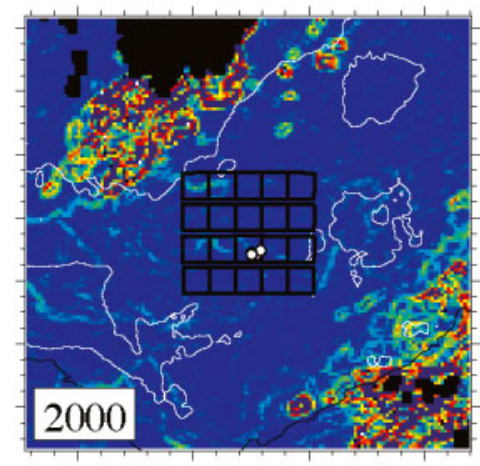

f
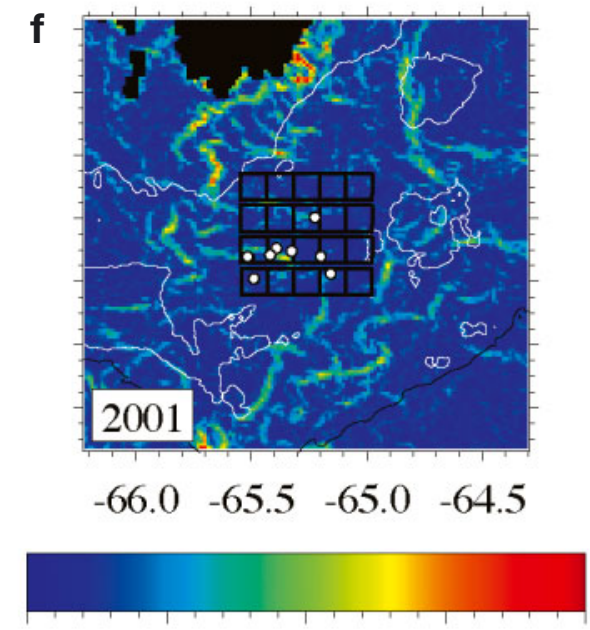

$\begin{array}{lllll}0.0 & 0.5 & 1.0 & 1.5 & 2.0\end{array}$

Sea Surface Temperature Gradient $\left({ }^{\circ} \mathrm{C} \mathrm{km}^{-1}\right)$

Fig. 6. Eubalaena glacialis. $(\mathrm{a}, \mathrm{c}, \mathrm{e})$ Sea surface temperature and $(\mathrm{b}, \mathrm{d}, \mathrm{f})$ corresponding SST gradient images associated with the (a,b) 1999, (c,d) 2000 and (e,f) 2001 Roseway Basin surveys. Completed survey units are indicated with boxes and right whale sightings are shown as white circles. Cloud contamination occurs as areas of locally colder temperatures and unrealistically high gradients in the southern and eastern portions of the 1999 images and in the NW (off Cape Sable) and SE portions of the 2000 images. The 2001 images are cloud-free 
spatial scales investigated here, ocean fronts on the southwestern Scotian Shelf probably serve a similar aggregative role as closed circulation does in the lower Bay of Fundy. Both physics and animal behavior at a front can promote horizontal and vertical aggregation of Calanus finmarchicus (Olson \& Backus 1985, Epstein \& Beardsley 2001), which produce greater prey concentrations at the comparatively small spatial scales required by filter-feeding right whales.

An association between right whales and ocean fronts in the Great South Channel was reported by Brown \& Winn (1989), but surface temperature gradients near the whales were low, and the animals occurred at a median distance of $11.4 \mathrm{~km}$ from the persistent front that occurs there in late spring. Brown \& Winn (1989) found that right whales remained on the northern, stratified side of this front in a region characterized by warmer surface temperatures. These stratified conditions occur in deep water depths $(>100 \mathrm{~m})$ and are associated with cyclonic currents (Chen et al. 1995) that provide closed circulation in the central Great South Channel (the 'SCOPEX' gyre). Miller et al. (1998) suggest that late-stage Calanus finmarchicus from 2 separate generations accumulate in this gyre during the spring. The existence of 2 aggregative mechanisms in the Great South Channel, namely a persistent ocean front and closed circulation, may provide profitable foraging grounds for right whales in years of high C. finmarchicus productivity and survivorship.

Our analysis of interannual variability in right whale occurrence must be viewed with caution in light of the short duration of the study. Moreover, interannual variation for some environmental observations was not independent in adjacent survey units. For instance, observations of SST in all Roseway Basin survey units simultaneously decreased from 1999 to 2000 and again from 2000 to 2001 (Fig. 6). Nonetheless, the tentative trends identified here (i.e. increasing sighting probability with decreasing SST) seem consistent with conditions that promote increased abundance of Calanus finmarchicus. Interannual (Meise-Munns et al. 1990, Conversi et al. 2001) and spatial (Meise \& O'Reilly 1996) variability in C. finmarchicus $C 5$ abundance are negatively correlated with water temperature in the Gulf of Maine in the summer and fall. These relationships likely reflect more complex variability in factors that affect $C$. finmarchicus productivity at time scales of several years, such as wind mixing, surface stratification and phytoplankton production (Fromentin \& Planque 1996, Conversi et al. 2001). Interannual and spatial variability in hydrographic conditions can potentially affect survivorship of $C$. finmarchicus as well. C. finmarchicus C5 are not thought to feed while in diapause (Hirche 1983, but see Durbin et al. 1995), but instead rely on their abundant oil reserves to survive throughout the summer and fall. Warmer temperatures increase the rate at which these oil reserves are metabolized and mortality occurs when reserves are depleted (Sameoto \& Herman 1990).

Survival of Calanus finmarchicus C5 may also decrease in warmer temperatures due to an increase in predatory, warm-water gelatinous zooplankton. Hydrographic conditions in Roseway Basin changed markedly from warm, salty waters in $1999(n=13$, average SST = $16.10^{\circ} \mathrm{C}$, average BML temperature $=6.87^{\circ} \mathrm{C}$, average BML salinity $=33.41 \mathrm{PSU}$ ) to cool, fresher waters in $2001\left(\mathrm{n}=20\right.$, average $\mathrm{SST}=11.76^{\circ} \mathrm{C}$, average $\mathrm{BML}$ temperature $=4.64^{\circ} \mathrm{C}$, average BML salinity $=33.06$ PSU) (Fig. 6). Zooplankton samples from this region in 1999 contained high abundances of gelatinous zooplankton $(n=4)$, but none of these animals were found in samples collected in $2000(\mathrm{n}=3)$ and $2001(\mathrm{n}=3)$. Predation by gelatinous zooplankton may have reduced C. finmarchicus C5 abundance in Roseway Basin, making this region unsuitable for right whales in 1999. Alternatively, gelatinous animals may be a nuisance to right whales because these zooplankton can clog the whales' baleen. Mayo \& Marx (1990) observed right whales 'flushing' their baleen in Cape Cod Bay, which probably functions to remove the viscous organic material and small particulates (including small zooplankton) that are abundant in these waters during spring. In contrast, we observed no flushing behavior in the lower Bay of Fundy, probably because right whales fed on C. finmarchicus C5 at depths where the concentration of suspended organic material and smaller zooplankton was very low. If the vertical distributions of $C$. finmarchicus $\mathrm{C} 5$ and predatory gelatinous zooplankton coincide in Roseway Basin, then the baleen of feeding right whales would be subject to clogging. The consequent reduction in filtering efficiency or the increase in time required to clear the baleen of debris may make foraging in Roseway Basin unprofitable in years of high gelatinous zooplankton abundance.

Predictive modeling of right whale distribution is a management objective with important conservation implications. Provided the appropriate environmental variables are readily available for input into such a model, one would be able to predict regions where right whales are likely to occur. The present research suggests specific variables that may be useful for predicting the spatial distribution of right whale occurrence in the study areas within a particular year. These include depth and BML depth for both the lower Bay of Fundy and Roseway Basin as well as SST gradient for Roseway Basin. However, prediction within each of these survey areas is presently of limited use. A more useful system would predict right whale occurrence in other areas as well. Extrapolation 
of our results to other regions of the spring-summerfall feeding grounds is unwise, however, since Calanus finmarchicus abundance is likely influenced by other factors in other regions and at other times. For instance, C. finmarchicus probably do not associate with a BML during the spring since feeding is observed in the upper portion of the water column (Watkins \& Schevill 1976, Mayo \& Marx 1990, Winn et al. 1995). Also, the importance of depth in this study is related to the aggregation of $C$. finmarchicus $\mathrm{C} 5$ in shelf basins; however, a similar relationship would not be expected in Cape Cod Bay, where right whales feed in areas less than $20 \mathrm{~m}$ deep (Mayo \& Marx 1990). Quantitative examination of right whale occurrence in relation to environmental factors is needed in the other major feeding areas to provide the scientific foundation for a predictive model.

One challenge in these modeling efforts is the availability of relevant environmental variables for inclusion in a predictive model. A hypothetical model for the lower Bay of Fundy and Roseway Basin might require depth, BML depth and SST gradient. Depth is available as a gridded, bathymetric dataset and SST gradient is available as a remotely sensed product from an AVHRR archive (e.g. Cornillon et al. 1987), but BML depth cannot presently be obtained remotely. One attractive solution to this problem is to use the output from an operational ocean model (e.g. Aikman et al. 1996, Kelley et al. 1997). These regional models can provide synoptic forecasts of vertically resolved temperature, salinity and currents and with which right whale distribution may be predicted for several days in advance. While much work remains to be done, including additional right whale ecology research, habitat model development, integration with existing ocean model forecast products and rigorous validation of model predictions, a predictive model with forecast capabilities has compelling promise: improved management of human activities within ephemeral right whale habitats to reduce anthropogenic sources of mortality in this endangered population.

Acknowledgements. We are grateful to S. Cummings, T. Durbin, P. Ortner, J. Prezioso, M. Taylor and R. Trask for providing equipment during this study. R. Campbell and G. Teegarden assisted with the 2001 MOCNESS tows. C. Miller and C. Ashjian graciously provided laboratory space and equipment to process the zooplankton samples. P. Cornillon and D. Holloway provided the AVHRR data. This study could not have been done without the hard work and good humor of the marine mammal observers: A. Barney, M. Bessinger, I. Briga, M. Canode, W. Chan, J. Ciano, J. Conner, H. Corbett, G. Cristiciello, R. DeVito, P. Duley, P. Feige, T. Fernald, L. Hatch, H. Herendeen, L. Irvine, B. Jann, L. Johnson, L. Kitson, C. Kitts, B. Lagerquist, A. Lamb, J. Mocklin, E. Montie, J. Nicolas, R. Pace, S. Perry, D. Pitassy, V. Portway, C. Potter, E. Power, H. Richmond, A. Stimpert, S. Valentine, F. Wenzel, S.
Wetmore, S. Wilkin and K. Willis. We would also like to thank the master, captain, officers and crew of NOAA Ships 'Delaware II' and 'Albatross IV' for their able assistance in the field. We are grateful to C. Miller, D. Palka, F. Serchuk, L. Ballance and 2 anonymous reviewers for commenting on earlier drafts of this manuscript. Support for this work was provided by the National Marine Fisheries Service, Office of Naval Research and the Oregon State University Marine Mammal Endowment. M.F.B. was supported by the Space Grant and Earth System Science fellowship programs of the National Aeronautics and Space Administration.

\section{LITERATURE CITED}

Aikman F III, Mellor GL, Ezer T, Sheinin D, Chen P, Breaker L, Bosley K, Rao DB (1996) Towards an operational nowcast/forecast system for the U.S. East Coast. In: MalanotteRizzoli P (ed) Modern approaches to data assimilation in ocean modeling. Elsevier Oceanography Series, Vol 61. Elsevier Science, New York, NY, p 347-376

Baumgartner MF (1997) The distribution of Risso's dolphin (Grampus griseus) with respect to the physiography of the northern Gulf of Mexico. Mar Mamm Sci 13:614-638

Baumgartner MF (2003) Comparisons of Calanus finmarchicus fifth copepodite abundance estimates from nets and an optical plankton counter. J Plankton Res 25: 855-868

Baumgartner MF, Mate BR (2003) Summertime foraging ecology of North Atlantic right whales. Mar Ecol Prog Ser 264:123-135

Baumgartner MF, Mullin KD, May LN, Leming TD (2001) Cetacean habitats in the northern Gulf of Mexico. Fish Bull 99:219-239

Baumgartner MF, Cole TVN, Campbell RG, Teegarden GJ, Durbin EG (2003) Associations between North Atlantic right whales and their prey, Calanus finmarchicus, over diel and tidal time scales. Mar Ecol Prog Ser 264:155-166

Beardsley RC, Epstein AW, Chen C, Wishner KF, Macaulay MC, Kenney RD (1996) Spatial variability in zooplankton abundance near feeding right whales in the Great South Channel. Deep-Sea Res II 43:1601-1625

Brown CW, Winn HE (1989) Relationship between the distribution pattern of right whales, Eubalaena glacialis, and satellite-derived sea surface thermal structure in the Great South Channel. Contin Shelf Res 9:247-260

Bumpus DF (1960) Sources of water contributed to the Bay of Fundy by surface circulation. J Fish Res Board Canada 17:181-197

CETAP (1982) A characterization of marine mammals and turtles in the mid- and north Atlantic areas of the U.S. outer continental shelf. Cetacean and Turtle Assessment Program, Final Report, Bureau of Land Management, Washington, DC

Chen C, Beardsley RC, Limeburner R (1995) Variability of currents in late spring in the northern Great South Channel. Contin Shelf Res 15:451-473

Clapham PJ, Young SB, Brownell RL Jr (1999) Baleen whales: conservation issues and the status of the most endangered populations. Mamm Rev 29:35-60

Conversi A, Piontkovski S, Hameed S (2001) Seasonal and interannual dynamics of Calanus finmarchicus in the Gulf of Maine (northeastern US shelf) with reference to the North Atlantic Oscillation. Deep-Sea Res II 48: $519-530$

Cornillon P, Gilman C, Stramma L, Brown O, Evans R, Brown $\mathrm{J}$ (1987) Processing and analysis of large volumes of 
satellite-derived thermal infrared data. J Geophys Res 92: 12 993-13002

Durbin EG, Campbell RG, Gilman SL, Durbin AG (1995) Abundance, biomass, vertical migration and estimated development rate of the copepod Calanus finmarchicus in the southern Gulf of Maine during late spring. Contin Shelf Res 15:571-591

Epstein AW, Beardsley RC (2001) Flow-induced aggregation of plankton at a front: a 2-D Eulerian model study. DeepSea Res II 48:395-418

Fish CJ, Johnson MW (1937) The biology of the zooplankton population in the Bay of Fundy and Gulf of Maine with special reference to production and distribution. J Biol Board Can 3:189-322

Fromentin JM, Planque B (1996) Calanus and environment in the eastern North Atlantic. II. Influence of the North Atlantic Oscillation on C. finmarchicus and C. helgolandicus. Mar Ecol Prog Ser 134:111-118

Gaskin DE (1987) Updated status of the right whale, Eubalaena glacialis, in Canada. Can Field-Nat 101:295-309

Greenberg DA (1983) Modeling the mean barotropic circulation in the Bay of Fundy and Gulf of Maine. J Phys Oceanogr 13:886-904

Godin G (1968) The 1965 current survey of the Bay of Fundy: a new analysis of the data and an interpretation of results. Mansucript Rep Ser No. 8, Marine Sciences Branch, Energy Mines and Resources, Ottawa

Hachey HB, Bailey WB (1952) The general hydrography of the waters of the Bay of Fundy. Fish Res Board Can Rep Biol Sta No. 455, Ottawa

Herman AW (1988) Simultaneous measurement of zooplankton and light attenuance with a new optical plankton counter. Contin Shelf Res 8:205-221

Herman AW (1992) Design and calibration of a new optical plankton counter capable of sizing small zooplankton. Deep-Sea Res 39:395-415

Herman AW, Sameoto DD, Shunnian C, Mitchell MR, Petrie B, Cochrane N (1991) Sources of zooplankton on the Nova Scotia Shelf and their aggregations within deep-shelf basins. Contin Shelf Res 11:211-238

Hirche HJ (1983) Overwintering Calanus finmarchicus and Calanus helgolandicus. Mar Ecol Prog Ser 11:281-290

Hosmer DW, Lemeshow S (2000) Applied logistic regression, 2nd edn. John Wiley \& Sons, New York, NY

Hui CA (1979) Undersea topography and distribution of dolphins of the genus Delphinus in the southern California Bight. J Mammal 60:521-527

Hui CA (1985) Undersea topography and the comparative distributions of 2 pelagic cetaceans. Fish Bull 83: $472-475$

Kelley JGW, Aikman F III, Breaker LC, Mellor GL (1997) Coastal ocean forecasts. Sea Technol 38:10-17

Kenney RD (2001) Anomalous 1992 spring and summer right whale (Eubalaena glacialis) distributions in the Gulf of Maine. J Cetacean Res Manage Spec Issue 2:209-223

Kenney RD, Kraus SD (1993) Right whale mortality-a correction and an update. Mar Mamm Sci 9:445-446

Kenney RD, Winn HE, Macaulay MC (1995) Cetaceans in the Great South Channel, 1979-1989: right whale (Eubalaena glacialis). Contin Shelf Res 15:385-414

Knowlton AR, Kraus SD (2001) Mortality and serious injury of northern right whales (Eubalaena glacialis) in the western North Atlantic Ocean. J Cetacean Res Manage Spec Issue 2:193-208

Kraus SD (1990) Rates and potential causes of mortality in North Atlantic right whales (Eubalaena glacialis). Mar Mamm Sci 6:278-291
Kraus SD, Prescott JH, Turnbull PV, Reeves RR (1982) Preliminary notes on the occurrence of the North Atlantic right whale (Eubalaena glacialis) in the Bay of Fundy. Rep Int Whal Commn 32:407-411

Lauzier LM (1967) Bottom residual drift on the continental shelf area of the Canadian Atlantic coast. J Fish Res Board Can 24:1845-1859

Lynch DR, Ip JTC, Naimie CE, Werner FE (1996) Comprehensive coastal circulation model with application to the Gulf of Maine. Contin Shelf Res 16:875-906

Mate BR, Nieukirk SL, Kraus SD (1997) Satellite-monitored movements of the northern right whale. J Wild Manage 61:1393-1405

Mayo CA, Marx MK (1990) Surface foraging behavior of the North Atlantic right whale, Eubalaena glacialis, and associated zooplankton characteristics. Can J Zool 68: $2214-2220$

Meise CJ, O'Reilly JE (1996) Spatial and seasonal patterns in abundance and age-composition of Calanus finmarchicus in the Gulf of Maine and on Georges Bank: 1977-1987. Deep-Sea Res II 43:1473-1501

Meise-Munns C, Green J, Ingham M, Mountain D (1990) Interannual variability in the copepod populations of Georges Bank and the western Gulf of Maine. Mar Ecol Prog Ser 65:225-232

Miller CB, Lynch DR, Carlotti F, Gentleman W, Lewis CVW (1998) Coupling of an individual-based population dynamic model of Calanus finmarchicus to a circulation model for the Georges Bank region. Fish Oceanogr 7: 219-234

Mitchell E, Kozicki VM, Reeves RR (1986) Sightings of right whales, Eubalaena glacialis, on the Scotian Shelf, 1966-1972. Rep Int Whal Commn Spec Issue 10:83-107

Murison LD, Gaskin DE (1989) The distribution of right whales and zooplankton in the Bay of Fundy, Canada. Can J Zool 67:1411-1420

NGDC (1988) Digital relief of the surface of the Earth. National Oceanic and Atmospheric Administration Data Announcement 88-MGG-02, National Geophysical Data Center, Boulder, CO

Olson DB, Backus RH (1985) The concentrating of organisms at fronts: a cold-water fish and a warm-core Gulf Stream ring. J Mar Res 43:113-137

Payne PM, Wiley DN, Young SB, Pittman S, Clapham PJ, Jossi JW (1990) Recent fluctuations in the abundance of baleen whales in the southern Gulf of Maine in relation to changes in selected prey. Fish Bull 88:687-696

Ramsey FL, Schafer DW (1997) The statistical sleuth: a course in methods of data analysis. Duxbury Press, Belmont, CA

Russ JC (1995) The image processing handbook, 2nd edn. CRC Press, Boca Raton

Sameoto DD, Herman AW (1990) Life cycle and distribution of Calanus finmarchicus in deep basins on the Nova Scotia shelf and seasonal changes in Calanus spp. Mar Ecol Prog Ser 66:225-237

Selzer LA, Payne PM (1988) The distribution of white-sided (Lagenorhynchus acutus) and common dolphins (Delphinus delphis) vs. environmental features of the continental shelf of the northeastern United States. Mar Mamm Sci 4: 141-153

Smith WHF, Sandwell DT (1997) Global seafloor topography from satellite altimetry and ship depth soundings. Science 277:1957-1962

Stone GS, Kraus SD, Prescott JH, Hazard KW (1988) Significant aggregations of the endangered right whale, Eubalaena glacialis, on the continental shelf of Nova Scotia. Can Field-Nat 102:471-474 
Watkins WA, Schevill WE (1976) Right whale feeding and baleen rattle. J Mammal 57:58-66

Weinrich MT, Kenney RD, Hamilton PK (2000) Right whales (Eubalaena glacialis) on Jeffreys Ledge: a habitat of unrecognized importance? Mar Mamm Sci 16:326-337

Wiebe PH, Burt KH, Boyd SH, Morton AW (1976) A multiple opening/closing net and environmental sensing system for sampling zooplankton. J Mar Res 34:313-326

Wiebe PH, Morton AW, Bradley AM, Backus RH, Craddock JE, Barber V, Cowles TJ, Flierl GR (1985) New developments in the MOCNESS, an apparatus for sampling zooplankton and micronekton. Mar Biol 87:313-323

Winn HE, Price CA, Sorensen PW (1986) The distributional biology of the right whale (Eubalaena glacialis) in the western North Atlantic. Rep Int Whal Comm Spec Issue 10:129-138

Winn HE, Goodyear JD, Kenney RD, Petricig RO (1995)

Editorial responsibility: Kenneth Sherman (Contributing

Editor), Narragansett, Rhode Island, USA
Dive patterns of tagged right whales in the Great South Channel. Contin Shelf Res 15:593-611

Wishner K, Durbin E, Durbin A, Macaulay M, Winn $\mathrm{H}$, Kenney R (1988) Copepod patches and right whales in the Great South Channel off New England. Bull Mar Sci 43:825-844

Wishner KF, Schoenherr JR, Beardsley R, Chen C (1995) Abundance, distribution and population structure of the copepod Calanus finmarchicus in a springtime right whale feeding area in the southwestern Gulf of Maine. Contin Shelf Res 15:475-507

Woodley TH, Gaskin DE (1996) Environmental characteristics of North Atlantic right and fin whale habitat in the lower Bay of Fundy, Canada. Can J Zool 74:75-84

Xue H, Chai F, Pettigrew NR (2000) A model study of the seasonal circulation in the Gulf of Maine. J Phys Oceanogr 30:1111-1135

Submitted: February 27, 2003; Accepted: September 15, 2003 Proofs received from author(s): December 2, 2003 